\title{
Rewriting Gender in Time of War: The Stage Debut of Le Soulier de Satin 1
}

\author{
Kenneth Krauss \\ College of St. Rose, Albany, NY
}

T

he premiere of Paul Claudel's Le Soulier de Satin at the Comédie Française late in November, 1943 is regarded as one of the high Nevertheless, its long-awaited opening received very mixed notices. In the collaborationist press, critics who hated conservative but antiGerman Claudel and his avant-garde co-adaptor, director, and leading actor, Jean-Louis Barrault, did not hesitate to castigate the production. After the War, some-including Merrill Rosenberg (139-140) and Patrick Marsh (351-3)-would claim that the piece was pulled from the repertory in May, 1944 because it was seen as a resistance play, a view that the condemnations of the French fascist press would help substantiate, as would the praise of Communist Resistance reviewer Claude Roy (Joubert 324, 328). (Marie-Agnès Joubert [322] and Christopher Flood [18] blame the electricity shortages.)

Yet amid the more conventional political controversies of the time, the realization of Le Soulier was also the site of a more subtle cultural and theatrical conflict involving sexuality. This conflict emerged in performance, much as it did through many of the plays of the Occupation, indirectly. The years between when the play was completed (1929) and when the play, in a version "pour la scène," finally came to the stage, widened the gap between its author's intent and its director's vision. Although spectators were aware of the disparity, they had no real framework through which to comprehend it. As a result, this landmark production has remained suspended not in time but in significance.

Even by 1949, with the start of postwar feminism, the problem revealed by the 1943 production lay beyond what one could explain. Simone de Beauvoir, in The Second Sex, declared, taking the printed text of Le Soulier as a primary example,

Claudel does no more than express poetically the Catholic tradition.... Venerating woman in God, men 
treat her in this world as a servant, even holding that the more one demands complete submission of her, the more surely one will advance her along the road of her salvation. ... To sanctify this ranking in the name of the divine will is not at all to modify it, but on the contrary to intend its eternal fixation. (231)

Yet the same Beauvoir a decade later, in The Prime of Life (1960), remembered in very different terms the performance of 1943:

We had objected to a good many things in [Le Soulier de Satin] when we read it a few years before; but we had admired Claudel for successfully containing heaven and earth in a love affair ... The show... lasted for over four hours, yet it held us absolutely breathless. ... ...I was captivated by [Marie Bell's] speaking voice: she encompassed all Africa and the Americas, the desert and the oceans, in her vocal range; she seared one's very heart. Barrault was a frail Rodrigo indeed beside this burning bush. (564)

What had made this production of so "sexist" a drama so appealing? After all the political explanations, Beauvoir might eventually have admitted that the play she saw was dominated by its mighty heroine, Doña Prouhèze, personified in the debut by Bell. The pre-eminence of this female figure was made all the more emphatic, first, by the stage script's cutting of Day 4 of the original text, in which Rodrigue must live on without her, and, second, by the larger-than-life acting of its star.

Bell, in performance style, belonged to a line of Comédiennes whose training was (by modern standards) nearly operatic. Like Rachel and Bernhardt, she was a member of the latest generation of vocal sorceresses to command the vast stage and auditorium in the house of Molière. If, as Beauvoir comments, Barrault's Rodrigue was "frail" in comparison, his frailty was no doubt due to his own acting background, which had been developed under Charles Dullin in much smaller houses and which differed markedly from the grandeur of classical French tradition.

In his role as director, Barrault did curtail a particular aspect of Bell's character, one that in fact was implicit in Claudel's orignal script. He sought to supress what Frederick Brown calls, "the bisexual nature of a heroine modeled on Saint Joan" (435); Brown clearly has in mind here Scene XII of Day 1, in which Prouhèze, having donned men's clothing to 
escape her husband's protection, is confronted by her Guardian Angel. Indeed, Beauvoir recollected, "Marie Bell in male attire I found embarassing: I had imagined Doña Prouhèze as endowed with more boyish charm" (Prime 564). On a narrative level, Scene XII reveals, through the Angel's arguments with the heroine, heaven's view of Prouhèze's flight. Yet more profoundly, as the Angel hints at her own similarity to Prouhèze, the scene sets up an analogy of sorts; the female Guardian is to the travestied heroine as Prouhèze herself ought to be to Rodrigue. But, as Beauvoir protested, Bell did not make a credible male.

of course the company of the Comédie Française possessed renowned impersonation skills. In fact, all roles in the cast of Le Soulier had to be played by actors who, according to Vichy law, were Aryan. Thus Asian, African, and Semitic characters were represented by certifiable Frenchmen or -woman. Prouhèze's maid, Jobarbara, for instance, wore heavy dark makeup, while Rodrigue's Chinese servant and Japanese secretary were painted yellow and had, thanks to eye pencil, slanting eyes; Don Camille, Prouhèze's Islamic husband, with the aid of putty and pancake, resembled a Moor. Photographs and reviews of the 1943 production of Le Soulier reveal that the portrayals were highly convincing. Julien Berthau, noted a skeptical Jean Sylvain in L'Appel, was surprisingly realistic (63) as the farcical Chinese. Why did Barrault ensure that the exotics all looked authentic while the trouser role rang false?

This question is further compounded by a variety of theatrical issues, first of which is the familiarity of the cross-dressing heroine in European drama. From its beginnings, French romantic comedy, much like Elizabethan, utilized the device of a woman passing for a man. Yet in France, such characterizations figured rather differently than in England, where all players were male. In a play, for example, by Marivaux, the heroine was played by a female, and thus the transformation from female dress to male, while less complicated than in England, was all the more genuine.

Moreover, as Brown implies, there is an historical precedent for heroic female-to-male crossdressing that predates the advent of the French theatre: Jeanne d'Arc. Others have discussed the frequent representations of Joan on the French stage during the Occupation; indeed, Claude Vermorel's Jeanne in Jeanne avec nous, rightly or wrongly construed as a resistance heroine, paved the way for such alleged résistantes as Jean-Paul Sartre's Elèctre in Les Mouches and Jean Anouilh's Antigone. The figure of Joan remained an ambiguous one, claimed by 


\section{Kenneth Krauss}

Vichy and the French fascists, and also by various factions of the Resistance. Both sides, however, perceived her as a woman who had transcended her own and her culture's sexuality.

Finally, in the absence of the male-to-female crossdressing which had been common in England prior to the Restoration (and to some degree in Spain's Golden Age), there had thrived since the eighteenth century a theatrical (and also an operatic) tradition in France of actresses performing certain male characters. Disheartened by the few great parts for women, Bernhardt undertook the title roles in Hamlet, L'Aiglon, Ernani, and Lorenzaccio, this last also played by Falconetti (who was Carl Deryer's Joan) and Marguerite Jamois (who had also tried Hamlet). This sort of crossdressing was largely unknown-except for Peter Pan-in Britain and the United States. It formally died in France with Jamois's performance during the 1945-46 season of Musset's Lorenzo, but it had expired during the war years, when men were supposed to be men and women were anything but.

Indeed, the figuration of the masculine and the feminine was radically more restricted during (and even after) the war than before. The dominated women of Montherlant, the mundane and the antithetically ethereal women of Anouilh, the inquisitive but ultimately obedient women of Giraudoux, the brilliant though ineffective women in Sartrethese are largely the female characterizations best remembered from the Occupation. Yet the male characterizations-Ferrante and Georges Carrion, Créon, The Man from Bellac, and Oreste and Garcin-ultimately embody and valorize the power of manhood. Theatrically, one of the more blatant examples of such figuration came in Barrault's mise en scène for André Obey's version of the Suppliantes of Aeschylus and his original Huit cents mètres (in which Barrault also starred) at Roland-Garros Stadium in July, 1941. Here, the human body, with which Barrault had worked in such experimental pieces as Autour une mère (his adaptation of Faulkner's As I Lay Dying in 1935), became the major feature in the spectacle, with its displays of beefcake masculinity and graceful femininity. As journalists deployed the concept of the feminine to include all that which now appeared unmanly-- to Jews, Communists, homosexuals, and supporters of the fallen Republic-the depiction of the masculine moved to incorporate a rather literal and tangible virility.

Thus, even while Barrault deployed in Le Soulier many of the "Total Theatre" techniques he had used in Autour une mère, he did so in a way that at least appeared to be consonant with the current political 
order and its codes of sexuality. True, the production's use of the body, as the waves of the sea, as the thorn bushes separating Prouhèze from her would-be suitor, reflected his earlier work, but the displays of flesh here, unlike the double-bill at Roland Garros, exhibited-and some implied they flaunted-the female form. There was the scene (in Day 1) in which Prouhèze's African servant, Jobarbara, danced with bare breasts in the moonlight, and in the tableau that closes Day 2 (as well as Part I in the stage version), the Moon herself appeared in the nude. The glamorous costumes, many of them fantastic and carnival-like, not to mention revealing, along with the appearance of nakedness, led Berland (who had praised Berthau's Chinaman) to compare the play's visual images to what one saw at the Casino de Paris, the Folies-Bergère, and the FoliesWagram. There was no artsy beefcake here, just the parade of flesh one (especially if one were a German soldier) gladly paid to see in Paris bei nacht. To those, like the eternally noxious Alain Laubreaux, who claimed to be devout worshippers if not of God then of the Comédie Française, such theatre was alleged to be offensive.

After the war, with what came to be called "The Consecration of Paul Claudel," literary critics would proclaim the author the great Catholic playwright and Le Soulier his wartime gift to France. Yet, during the Occupation itself, in this era when many of the values of the Church were supposed to have been incorporated directly into the state, Le Soulier de Satin had proved very problematic. Only when France had once again become La République Française were commentators and reviewers able to appreciate Claudel's dramas for what the playwright wanted them to be. Jacques Guicharnaud, for example, insisted that his "works are didactic-not demonstrations but pure and simple affirmations" that operate for a Catholic audience as "the only true explanation" of the world. In spite of Guicharnaud's assertion that "faith does not allow of discussion" (67), drama certainly does. Indeed, the reason drama was expelled from the church was that it was too difficult to regulate: even the simplest faithful allegories gave rise to dangerous implications. All the same, to imagine a script as long and as convoluted as Le Soulier as a "simple" anything is not easy. To regard the message of this play as something other than the work in totality-to privilege those pieces of it that heavily promote the Church's prescribed constructs of sexuality and to discount all others-is to ignore the greater part of the play. The model of reception implicit in Guicharnaud's statement, and which coincides with Beauvoir's, overlooks the complexity of the playscript. 


\section{Kenneth Krauss}

The response to Le Soulier was politically motivated both during the Occupation and after the Liberation. Laubreaux's attacks on Claudel and Barrault were grounded in his fascist beliefs, but then Beauvoir's condemnation also stemmed from an ideology-from postwar feminism. In her wake, others have tried varied approaches to make sense of Claudel's contradictory figuration of women. "In every [play]," notes Jacques Lefebvre philosophically, "woman seems created for man, but in order to inflame in him a sorrowful desire" (57), as if to make consistent the ambivalent portrayal of sexuality. Michel Malicet's careful, Freudian analysis imposes the logic of psychology upon the uncomfortably paradoxical: "la "mystère' du personage feminin" is solved through the "explications dans la théorie psychoanalytique" (120). Dominique MilletGérard, through a Marxist-inspired vocabulary proposes, "la feminité claudelienne est essentialement double et révèle son sens le plus profond à travers une dialectique spirituelle qui transcende la singularité des 'rôles"' (17). In all three instances, critics deploy sophisticated means to harmonize what seems to them a distinct thematic dissonance.

Bettina Knapp, one of the very few to note an apparent discontinuity between written and performance texts, grounds her conclusions in a psychological discussion of the author: "Claudel's theological ideas are apparently an outgrowth of his inability to reconcile his sexual drive with his spiritual values" (140). "Yet," she continues, "as produced by Barrault, and when viewed symbolically as a dramatization of a vital theological problem, it neatly sets forth Claudel's viewpoint" (140-141). The most troubling word here, perhaps, is "neatly": Ultimately, Knapp agrees with Guicharnaud that Claudel is a successful "message" playwright.

The 1943 production of Le Soulier both promoted and denied Doña Prouhèze as herione. Marie Bell, unlike Antigone and Jeanne d'Arc, remained "all woman." The "bisexual nature of a heroine modeled on Saint Joan," as Brown puts it, might have led spectators to the notion that Prouhèze transcended sexuality and called into question the constructs solidified by the Occupiers and by Vichy. Whatever Barrault's political thoughts may have been (and surely he had some), he never challenged the cultural beliefs upon which gender was based. Indeed, his personal contribution to the changes regarding who played what was to eclipse Mme Sarah as Hamlet just after the defeat; it was his amazing debut at a societaire. In the first season after the War, Marguerite Jamois would play Lorenzo as "the Maquis member, the resistance fighter who mixed with the occupiers in order to seize their secrets and plans and deliver 


\section{Rewriting Gender in Time of War}

them to his own chiefs" in an act of "engagement" (Gastinel 352). But the actor whose postwar portrayal of Lorenzo would be remembered best was Gérard Philipe, who passed in life for the character whom Jamois created. The end of female-to-male cross-casting in French theatre is an inidcation of how deeply the Occupation influenced the major tenents underlying French culture. Barrault's staging of Le Soulier de Satin illuminates a moment when the great interpreter of the great playwright in the great theatre of France pulled back from what had come to be an accepted stage practice; thus, in his own small way and no doubt quite unknowingly, Barrault helped reconfigure French sexuality in order to make it consonant with the contructs upheld in Nazi Germany.

\section{Note}

1 Because of time constraints, only parts of this paper were read during the Claudel Society session; this constitutes the complete text. This paper does not examine the role of the Guardian Angel, a male role which Barrault cross-cast with a female actor; a later, much longer revision of this paper, in the form of a chapter in my forthcoming book, La Comedie sans Tickets: Studies in the Drama of Occupied France.

\section{Works Cited}

Beauvoir, Simone de. The Prime of Life. Peter Green trans. New York: VikingPenguin, 1965.

The Second Sex. New York: Vintage, 1989.

Brown, Frederick. Theatre and Revolution: The Culture of the French Stage. New York: Viking, 1980.

Flood, Christopher G. "Theatrical Triumph and Political Ambigioty: Le Soulier de satin at the Comédie Française in 1943-1944." French Cultural Studies, 3:17-30 (Febb. 1992).

Gastinel, Françoise. "Notice" to Lorenzaccio. Anna Gastinel, ed. Comédies et proverbes by Alfred de Musset, Vol. II. Paris: Société des Belles Lettres, 1952. 352-355. Guicharnaud, Jacques. Modern French Theatre: From Gircudoux to Genet. New Haven: Yale UP, 1967. (Yale Romanic Studies, 2nd Series, 7; rev. ed.)

Joubert, Marie-Agnès. La Comédie Française sous l'Occupation. Paris: Tallandier, 1998. 


\section{Kenneth Krauss}

Knapp, Bettina L. Paul Claudel. New York: Ungar, 1982.

Le Soulier de Satin: action espagnole en 2 parties de Paul Claudel, représenté pour la première fois, à la Comédie Française, le 27 Novembre 1943. R. Supp. 1453.

Lefebvre, Jacques. "La Femme dans le théâtre de Claudel." Revue Générale pour l'huministe des temps nouveaux, 4 (Apr. 1983), 57-68.

Malicet, Michel. "La Peur de la Femme dans Le Soulier de Satin." Paul Cladel 11 (1974): Les Images dans Le Soulier de Satin. Jacques Petit ed. La Revue des Lettres Modernes, nos. 391-397, 1974 (2). Paris: Lettres Modernes, Minard, 1974.

Marsh, Patrick. "Le Théâtre à Paris sous l'occupation allemande." Revue de la Société d'histoire de Théâtre, 33.3 (1981): 197-369.

Millet-Gérard, Dominique. "La Figure féminine chez Claudel." Claudel Studies, 15:1 (1988), 17-28.

Rosenberg, Merrill A. "Vichy's Theatrical Venture." Theatre Survey, 11:124-50 (1970). 